\title{
DINAMIKA INDUSTRI RAWAI TUNA DI PELABUHAN BENOA
}

\author{
Dynamic of Industrial Tuna Longline in Benoa Port \\ Oleh: \\ Fathur Rochman ${ }^{*}$, Irwan Jatmiko ${ }^{2}$, Zulkarnaen Fahmi ${ }^{3}$
${ }^{1}$ Loka Riset Perikanan Tuna, Bali. fathursmasabio1@gmail.com
2 Loka Riset Perikanan Tuna, Bali.irwan.jatmiko@gmail.com
${ }^{3}$ Loka Riset Perikanan Tuna, Bali.fahmi.p4ksi@gmail.com

*Korespondensi : fathursmasabio1@gmail.com

Diterima: 12 April 2018; Disetujui: 25 Oktober 2018

\begin{abstract}
This study presents information about the dynamics of industrial scale tuna longline development in Indonesia, especially tuna longline fisheries in the Eastern Indian Ocean. This study uses a descriptive method based on tuna longline enumeration data landed at Benoa port from 2012 to 2015. Benoa is one of the three main fishing ports in Indonesia, besides Nizam Zachman (Jakarta) and Cilacap (Central Java). It contributes the largest number of tuna catches to $60 \%$ of the total long-scale tuna catch industry in the Indian Ocean. This makes Benoa as the main barometer of industrial tuna fisheries in Indonesia. Industrial scale of tuna longline fisheries activities have dropped significantly to 76\% from 2004 to 2015. Highest decline occurred in 2004 to 2006 by $43 \%$ followed by 2009 to 2010 at 41\% and 2014 to 2015 at 19\%. Enumeration data coverage in Benoa port is about $57 \%$ to $64 \%$ of total ship landing. Catch dominated by export products followed by local quality and bycatch products. The catch composition is dominated by four tuna species (BET, YFT, SBT and ALB) which reach $88 \%$ of the total catch followed by bycatch of $6.23 \%$ and fish with beaks of 5.46\%. In period 2012 to 2014, fishing efforts are directly proportional to the number of ships and tuna production, but in 2015, capture efforts, CPUE and catch production increased along with the decline in the number of ships operating.
\end{abstract}

Keyword: Benoa port, enumeration program, tuna longline

\begin{abstract}
ABSTRAK
Studi ini menyajikan informasi tentang dinamika perkembangan rawai tuna skala industri di Indonesia khususnya perikanan rawai tuna di Samudera Hindia Bagian Timur. Studi ini menggunakan metode deskriptif yang berbasis data enumerasi perikanan rawai tuna yang didaratkan di Pelabuhan Benoa tahun 2012 sampai dengan 2015. Pelabuhan Benoa merupakan satu dari tiga pelabuhan perikanan utama di Indonesia disamping Nizam Zachman (Jakarta) dan Cilacap (Jawa Tengah). Pelabuhan Benoa menyumbangkan jumlah tangkapan ikan tuna terbesar mencapai $60 \%$ dari total tangkapan rawai tuna skala industri di Samudera Hindia. Hal ini menjadikan Pelabuhan Benoa sebagai barometer utama perikanan tuna skala industri di Indonesia. Kegiatan perikanan rawai tuna skala industri telah menurun secara signifikan hingga $76 \%$ dari 2004 sampai 2015. Penurunan tertinggi terjadi pada 2004 sampai 2006 sebesar $43 \%$ diikuti 2009 hingga 2010 sebesar $41 \%$ dan 2014 sampai 2015 sebesar 19\%. Cakupan data enumerasi di Pelabuhan Benoa adalah 57\% sampai $64 \%$ dari total pendaratan kapal. Hasil tangkapan didominasi oleh produk ekport diikuti oleh produk kualitas lokal dan produk hasil sampingan. Komposisi hasil tangkapan didominasi oleh empat spesies tuna (BET, YFT, SBT dan
\end{abstract}


ALB) yang mencapai $88 \%$ dari total tangkapan diikuti oleh hasil tangkapan sampingan sebesar $6,23 \%$ dan ikan berparuh sebesar 5,46\%. Pada periode 2012 sampai 2014 , upaya penangkapan berbanding lurus dengan jumlah kapal dan produksi tuna namun pada tahun 2015 upaya penangkapan, CPUE dan produksi hasil tangkapan meningkat seiring dengan turunnya jumlah kapal yang beroperasi.

Kata kunci: Pelabuhan Benoa, program enumerasi, rawai tuna

\section{PENDAHULUAN}

Perikanan tuna Indonesia adalah salah satu yang terbesar di dunia terutama di Samudera Hindia Bagian Timur (Pillai \& Satheshkumar 2013). Total hasil tangkapan perikanan tuna Indonesia mencapai $15 \%$ dari total produksi perikanan tuna Samudera Hindia dengan perkiraan total pendaratan tuna sebesar 185.675 ton yang terdiri dari tuna sirip kuning 65.686 ton, tuna mata besar 34.400 ton, cakalang 79.999 tondan albakora 5.590 ton (DGCF 2014). Armada rawai tuna Indonesia terdiri dari 916 unit (2010), 1.083 unit (2011) (IOTC 2012). Pada tahun 2012, jumlah armada rawai tuna meningkat hingga 1.179 unit (Moreno \& Herrera 2013). Namun, pada akhir 2014 terjadi penurunan jumlah armada rawai tuna hingga $17 \%$ dari tahun sebelumnya. Hal ini terjadi karena pelaksanaan Peraturan Menteri Kelautan dan Perikanan Republik Indonesia nomor 56 tahun 2014 dan nomor 10 tahun 2015 tentang moratorium perikanan tangkap. Pelaksanaan moratorium dan evaluasi tersebut ditujukan kepada kapal-kapal yang pembuatannya dilakukan di luar negeri (Rochman et al. 2016a).

Indonesia memiliki tiga pelabuhan utama antara lain Benoa (Bali), Nizam Zachman (Jakarta) dan Cilacap (Jawa Tengah) (Proctor et al. 2003; Hutapea et al. 2017). Namun, kontribusi hasil tangkapan tertinggi diperoleh oleh Pelabuhan Benoa yang mencapai $60 \%$ dari total hasil tangkapan rawai tuna skala industri (Proctor et al. 2003). Oleh karena itu, perikanan rawai tuna skala industri di Pelabuhan Benoa dapat dijadikan sebagai barometer utama dalam dinamika perkembangan perikanan rawai tuna skala industri yang berbasis di Samudera Hindia. Perkembangan armada rawai tuna di Pelabuhan Benoa-Bali mengalami pasang-surut dan terkait langsung dengan kondisi sumberdaya ikan dan kebijakan pemerintah terutama dengan kenaikan harga BBM, kebijakan terkait illegal fishing dan moratorium penangkapan kapal ikan eks asing (Rochman \& Nugraha 2014; Rochman et al. 2016 a).
Tujuan studi ini adalah untuk mengetahui dinamika perkembangan rawai tuna skala industri di Pelabuhan Benoa berdasarkan hasil kajian program enumerasi dari tahun 2012 sampai dengan 2015. Keluaran dari kajian ini adalah dapat memberikan informasi kepada pengambil kebijakan sebagai dasar dalam mengelola perikanan tuna secara bertanggung jawab dan berkelanjutan.

\section{METODE}

Kajian ini berbasis data enumerasi yang dilakukan oleh Loka Riset Perikanan Tuna (LRPT) yang dimulai pada bulan Januari 2012 sampai dengan Desember 2015. Penentuan kapal yang dilakukan enumerasi menggunakan sampel acak dengan batas minimal $30 \%$ dari jumlah kapal yang mendaratkan hasil tangkapan di pelabuhan. Hal itu dilakukan untuk memenuhi persyaratan yang ditentukan oleh IOTC (IOTC 2002). Selanjutnya dilakukan pencatatan hasil tangkapan menggunakan metode sensus bagi kapal-kapal yang telah ditentukan. Metode sensus adalah teknik penentuan sampel bila semua anggota populasi digunakan sebagai sampel (Sugiyono 2008). Data hasil enumerasi yang dilakukan di Pelabuhan Benoa antara lain:

1. Data jumlah kapal yang sandar dan atau menitipkan hasil tangkapan di Pelabuhan Benoa per bulan dari Januari 2012 sampai dengan Desember 2015.

2. Produksi hasil tangkapan yang didaratkan di Pelabuhan Benoa yang meliputi: data produksi hasil tangkapan utama (exsport), data hasil tangkapan sampingan (by catch) dan data hasil tangkapan kualitas lokal (reject) akan dikirimkan ke pasar domestik atau diproses menjadi produk tertentu untuk di ekspor ke luar negeri. Terdapat beberapa spesies tuna yang didaratkan di Pelabuhan Benoa antara lain: tuna sirip kuning (Thunnus albacares), tuna mata besar (Thunnus obesus), tuna sirip biru selatan (Thunnus maccoyii), albakora (Thunnus alalunga) dan 
ikan berparuh (marlin, layaran, todak dan ikan pedang). Ikan tangkapan sampingan antara lain: bawal sabit, escolar, tengiri dan cucut.

3. CPUE (catch per unit of effort) hasil tangkapan $(\mathrm{kg})$ per satuan upaya penangkapan (trip) kapal yang mendaratkan dan atau menitipkan hasil tangkapan di Pelabuhan Benoa. Jika armada rawai tuna secara langsung atau menitipkan hasil tangkapan di kapal pengangkut carrier maka dianggap telah melakukan 1 kali upaya (trip). Menurut (Gunarso \& Wiyono 1994), CPUE dihitung menggunakan persamaan sebagai berikut :

CPUE $=\frac{\text { JumlahTangkapan }(\mathrm{kg})}{\text { JumlahUpayaPenangkapan (unit) }}$

Metode yang digunakan dalam penelitian ini adalah metode deskriptif dimana penelitian ini ditujukan untuk menggambarkan fenomena yang terjadi pada perikanan rawai tuna skala industri di Pelabuhan Benoa. Menurut Furchan (2004), penelitian deskriptif adalah penelitian yang menggambarkan fenomena-fenomena yang terjadi apa adanya dengan cara menelaah secara teratur, mengutamakan obyektifitas dan dilakukan secara cermat. Dalam penelitian deskriptif tidak terdapat perlakuan khusus, perlakuan yang dikendalikan serta pengujian hipotesis.

\section{HASIL}

\section{Armada Rawai Tuna dan Cakupan Data Enumerasi}

Aktivitas rawai tuna skala industri mengalami penurunan yang sangat signifikan mencapai 76\% dari 2004 sampai dengan 2015. Penurunan tertinggi terjadi pada tahun 2004 sampai tahun 2006 sebesar 43\%, diikuti tahun 2009 hingga tahun 2010 sebesar $41 \%$ dan selanjutnya pada tahun 2014 hingga tahun 2015 sebesar 19\% (Gambar 1).

Data kapal mendarat dan kapal yang berhasil disampling disajikan pada Gambar 2. Cakupan data enumerasi mencapai 57$64 \%$ dari total kapal yang mendaratkan hasil tangkapan di Pelabuhan Benoa (Gambar 3).

\section{Produksi, CPUE dan Komposisi Hasil Tangkapan}

Produksi perikanan rawai tuna skala industri di Pelabuhan Benoa dari tahun 2012 sampai dengan 2015 didominasi oleh produk ekspor dengan rata-rata sebesar 2.965 ton tahun $^{-1}$ diikuti oleh produk kualitas lokal sebesar 2.799 ton tahun ${ }^{-1}$ dan produk hasil tangkapan sampingan sebesar 1.792 ton tahun $^{-1}$ (Gambar 4a). Produksi tahunan tertinggi diperoleh pada tahun 2015 sebesar 8.291 ton tahun ${ }^{-1}$ diikuti tahun 2012 sebesar 7.791 ton tahun $^{-1}$, tahun 2014 sebesar 7.525 ton tahun $^{-1}$ dan tahun 2013 sebesar 6.816 ton tahun $^{-1}$ (Gambar 4b).

Hasil analisis komposisi hasil tangkapan diperoleh 26 spesies yang tertangkap oleh rawai tuna di Pelabuhan Benoa. Empat jenis tuna yang mendominasi hasil tangkapan antara lain: tuna mata besar $(33,72 \%)$, tuna sirip kuning $(29,83 \%)$, tuna sirip biru selatan (13,90\%) dan albakora (10,57\%). Disamping itu terdapat tangkapan ikan berparuh yang didominasi oleh ikan pedang $(3,92 \%)$, marlin biru $(1,16 \%)$, dan marlin hitam $(0,38 \%)$ (Tabel 1$)$.

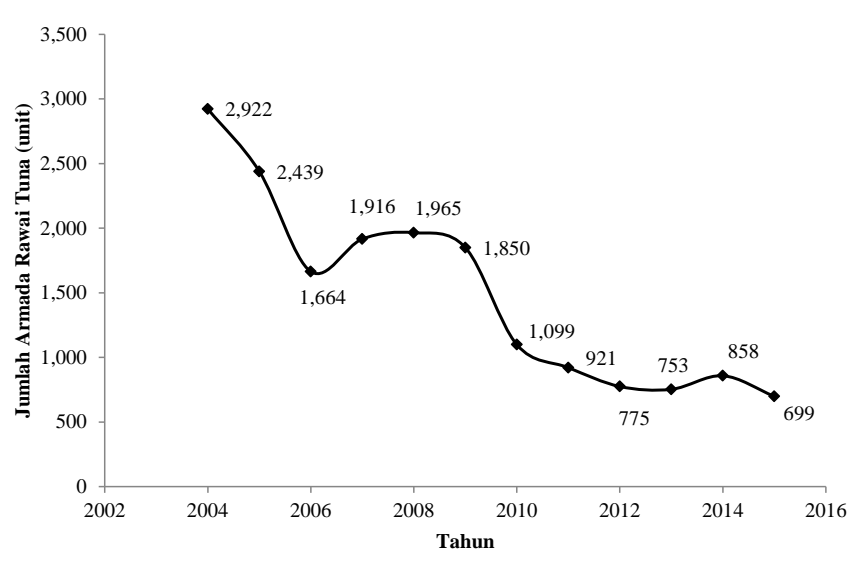

Gambar 1 Jumlah armada rawai tuna yang mendaratkan hasil tangkapan di Pelabuhan Benoa tahun 2004-2015 


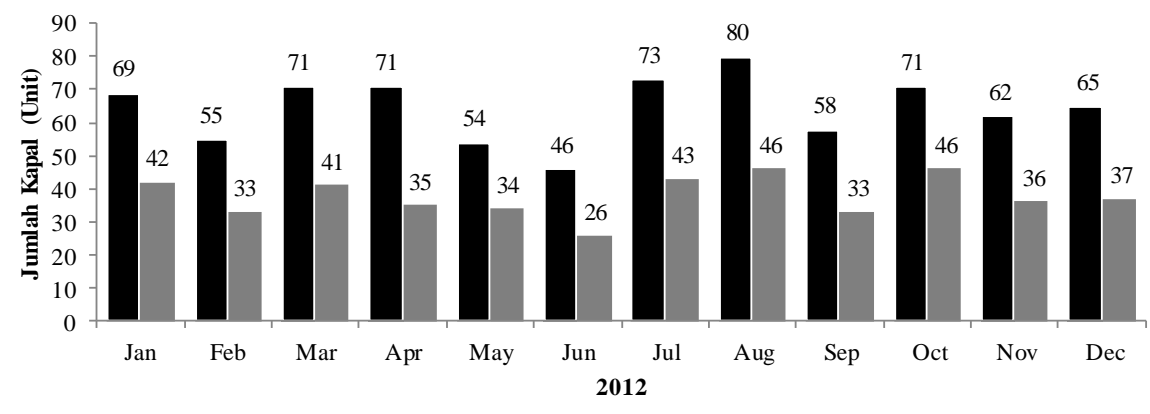

- kapal yang mendarat $\quad$ kapal yang disampling

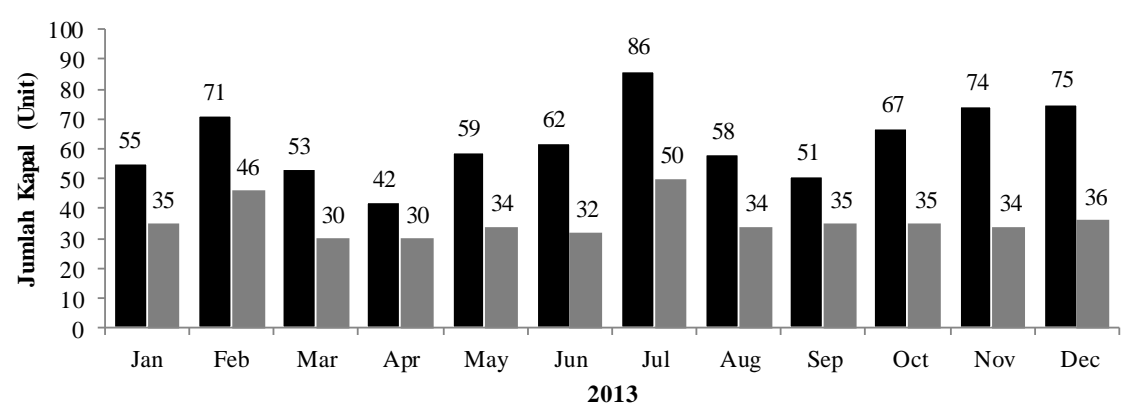

- kapal yang mendarat $\quad$ kapal yang disampling

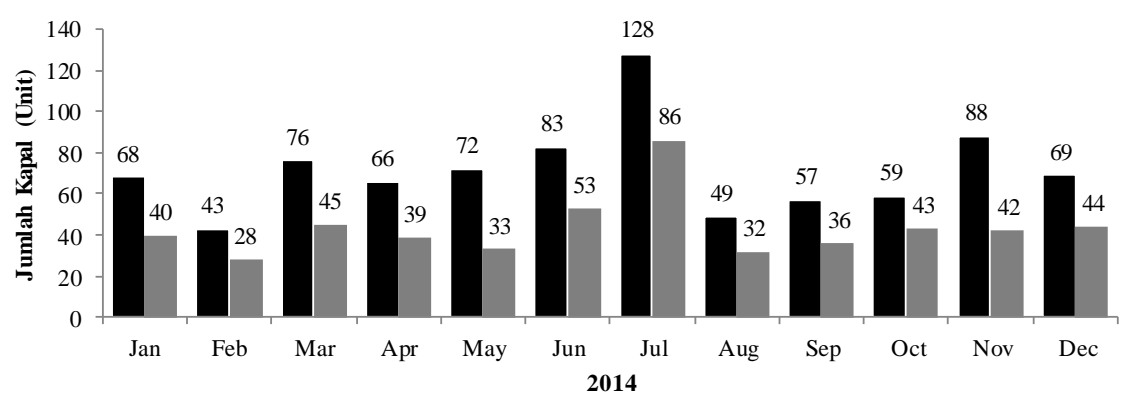

- kapal yang mendarat $\quad$ kapal yang disampling

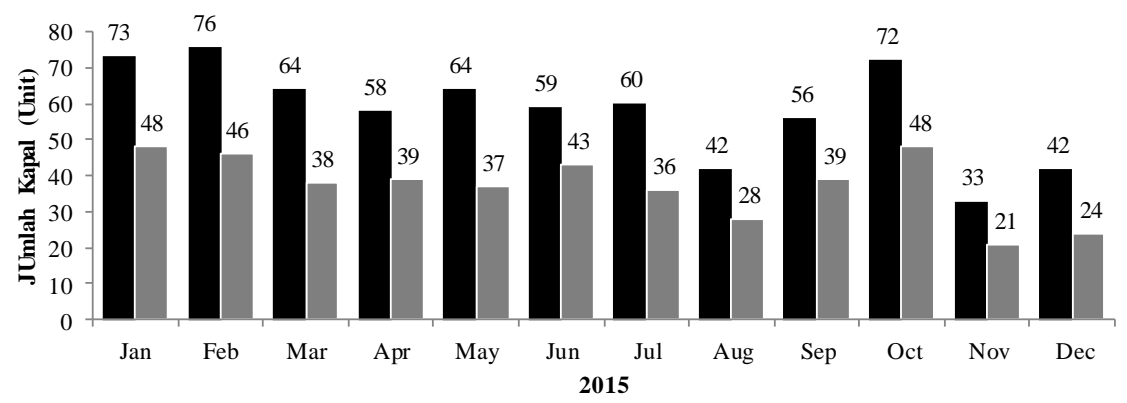

- kapal yang mendarat $\quad$ kapal yang disampling

Gambar 2 Jumlah kapal yang mendarat dan kapal yang disampling selama kegiatan enumerasi di Pelabuhan Benoa tahun 2012-2015 


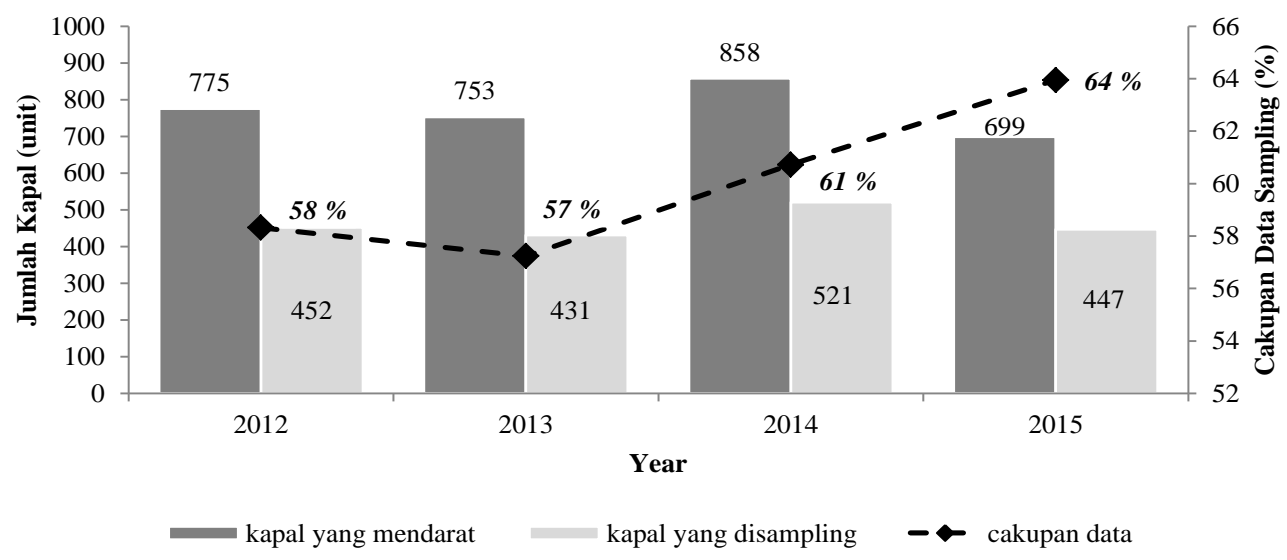

Gambar 3 Cakupan data enumerasi yang dilakukan oleh enumerator Loka Riset Perikanan Tuna tahun 2012-2015

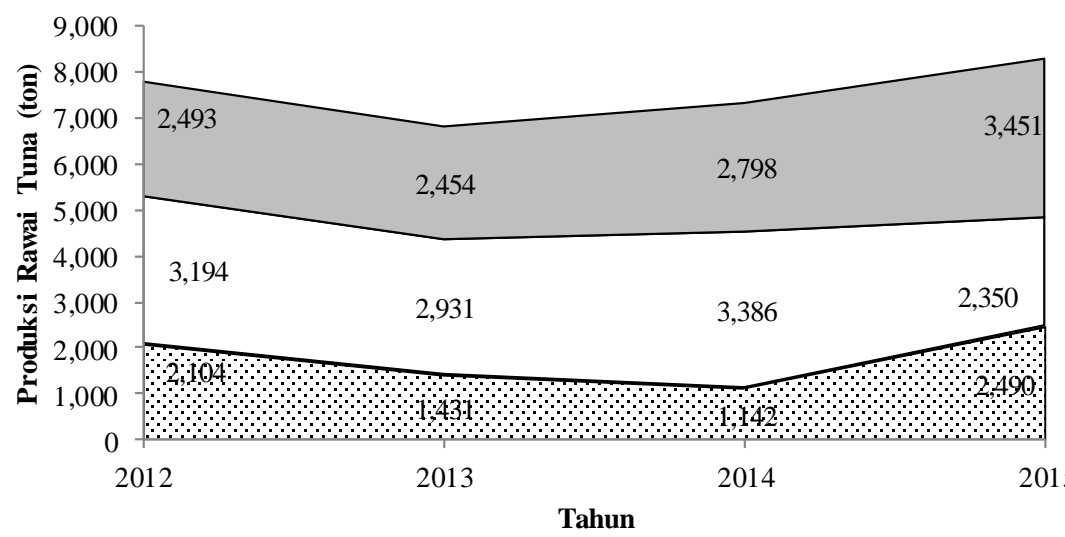

ÐTangkapan Sampingan $\square$ Eksport $\square$ Lokal

(a)

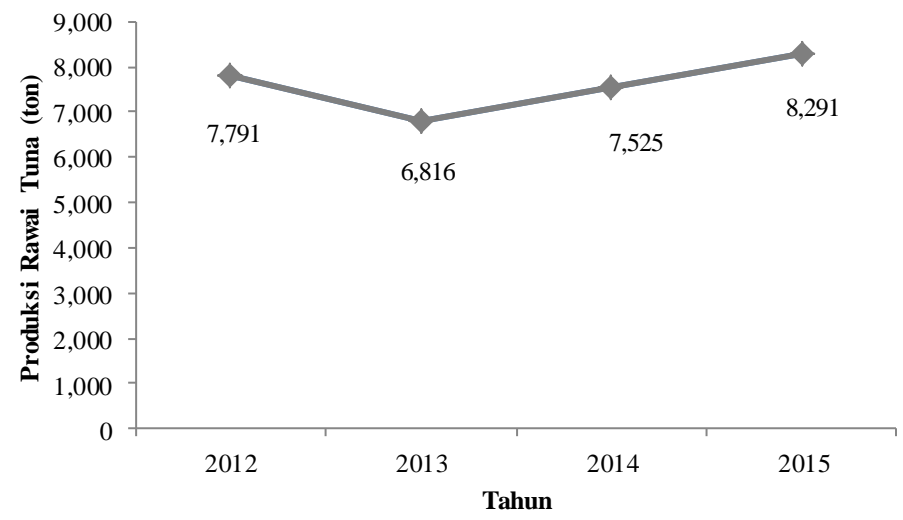

(b)

Gambar 4 Produksi tahunan rawai tuna skala industri yang didaratkan di Pelabuhan Benoa tahun 2012-2015. (a) berdasarkan jenis produk, (b) berdasarkan total tangkapan tahunan 
Pada tahun 2012, total produksi mencapai 7.791 ton tahun ${ }^{-1}$ dengan rata-rata 649 ton bulan $^{-1}$. Total upaya penangkapan sebesar 31.521 (hari laut) tahun $^{-1}$ dan ratarata upaya sebesar 2.627 (hari laut) bulan-1 (Gambar 5a).

Di tahun 2013, total produksi cenderung menurun dibandingkan tahun sebelumnya dengan total produksi sebesar 6.816 ton tahun $^{-1}$ dan 586 ton bulan ${ }^{-1}$. Total upaya sebanding dengan tahun sebelumnya sebesar 31.932 (hari laut) tahun $^{-1}$ dengan rata-rata upaya penangkapan sebesar 2.661 (hari laut) bulan-1 (Gambar 5b).

Di tahun 2014, total produksi meningkat dengan nilai menyamai perolehan tahun 2012 sebesar 7.525 ton tahun ${ }^{-1}$ dengan rata-rata sebesar 627 ton bulan-1. Disamping itu, total upaya penangkapan meningkat dibandingkan tahun sebelumnya sebesar
32.992 (hari laut) tahun ${ }^{-1}$ dengan rata-rata sebesar 2.749 (hari laut) bulan ${ }^{-1}$ (Gambar 5c).

Memasuki tahun 2015, total produksi perikanan rawai tuna meningkat secara signifikan sebesar 8.291 ton tahun ${ }^{-1}$ dengan rata-rata sebesar 691 ton bulan ${ }^{-1}$. Peningkatan total produksi diimbangi dengan peningkatan upaya penangkapan sebesar 32.501 (hari laut) tahun ${ }^{-1}$ dengan rata-rata sebesar 2.708 (hari laut) bulan-1 (Gambar $5 d)$.

Rata-rata hasil tangkapan per satuan upaya (CPUE) rawai tuna adalah sebesar $245 \mathrm{~kg}$ (hari laut) ${ }^{-1}$ di tahun 2012, $213 \mathrm{~kg}$ (hari laut) ${ }^{-1}$ di tahun $2013,232 \mathrm{~kg}$ (hari laut) $)^{-1} \mathrm{di}$ tahun 2014 dan $253 \mathrm{~kg}$ (hari laut) ${ }^{-1}$ di tahun 2015. CPUE tertinggi diperoleh pada tahun 2015 diikuti tahun 2012, 2014 dan 2013 (Tabel 2).

Tabel 1 Komposisi hasil tangkapan rawai tuna berdasarkan hasil enumerasi tahun $2012-2015$

\begin{tabular}{|c|c|c|c|c|c|c|c|}
\hline Species & Kode & 2012 & 2013 & 2014 & 2015 & Total & Persen. (\%) Keterangan \\
\hline Hiu Tikus & TSS & & 58 & 138 & 19 & 215 & $0.00 \mathrm{HTS}$ \\
\hline Cucut Lanjaman & SSH & & 1,284 & 72 & 509 & 1,865 & $0.01 \mathrm{HTS}$ \\
\hline Barakuda & BAR & 1,169 & 826 & 719 & 521 & 3,235 & $0.01 \mathrm{HTS}$ \\
\hline Bawal Bulat & TCR & 1,618 & 994 & 1,256 & 2,126 & 5,994 & $0.03 \mathrm{HTS}$ \\
\hline Layur Putih & HAR & 18 & 0 & 0 & 6,374 & 6,392 & $0.03 \mathrm{HTS}$ \\
\hline Cakalang & SKJ & 3,362 & 1,394 & 477 & 1,310 & 6,543 & $0.03 \mathrm{HTS}$ \\
\hline Lamadang & CDF & 2,404 & 1,708 & 1,138 & 2,649 & 7,899 & $0.04 \mathrm{HTS}$ \\
\hline Todak & SSP & 2,636 & 2,174 & 609 & 2,837 & 8,256 & $0.04 \mathrm{HTS}$ \\
\hline Bawal Sabit & TST & 4,485 & 2,719 & 1,426 & 2,530 & 11,160 & $0.05 \mathrm{HTS}$ \\
\hline Hiu Tenggiri & MSO & 5,696 & 3,324 & 2,626 & 3,883 & 15,529 & $0.07 \mathrm{HTS}$ \\
\hline Bawal Astro & BUK & & 0 & 1,902 & 19,049 & 20,951 & 0.09 HTS \\
\hline Cucut Koboy & OCS & 8,801 & 4,799 & 2,197 & 6,703 & 22,500 & $0.10 \mathrm{HTS}$ \\
\hline Marlin Loreng & MLS & 10,076 & 12,769 & 2,711 & 3,931 & 29,487 & $0.13 \mathrm{HTS}$ \\
\hline Layaran & SFA & 8,538 & 10,978 & 4,940 & 8,089 & 32,545 & $0.14 \mathrm{HTS}$ \\
\hline Ikan setan Sisik Berduri & OIL & 4,990 & 9,162 & 8,131 & 20,167 & 42,450 & $0.19 \mathrm{HTS}$ \\
\hline Tengiri & WAH & 27,080 & 17,975 & 13,903 & 15,792 & 74,750 & $0.33 \mathrm{HTS}$ \\
\hline Marlin Hitam & BLM & 29,989 & 32,758 & 15,239 & 6,973 & 84,959 & $0.38 \mathrm{HTS}$ \\
\hline Cucut Selendang Biru & $\mathrm{BSH}$ & 62,917 & 38,940 & 23,239 & 97,065 & 222,161 & 0.99 HTS \\
\hline Marlin Biru & BUM & 71,868 & 100,690 & 42,404 & 46,901 & 261,863 & $1.16 \mathrm{HTS}$ \\
\hline Ikan Setan Abu-abu & LEC & 164,997 & 147,177 & 76,213 & 78,102 & 466,489 & 2.07 HTS \\
\hline Opah & MON & 59,675 & 81,821 & 123,362 & 224,599 & 489,457 & 2.17 HTS \\
\hline Ikan Pedang & SWO & 217,726 & 287,977 & 171,048 & 205,672 & 882,423 & $3.92 \mathrm{HTS}$ \\
\hline Albakora & ALB & 711,613 & 850,655 & 430,223 & 388,317 & $2,380,808$ & 10.57 HTU \\
\hline Tuna Sirip Biru Selatan & SBF & 364,657 & 798,179 & 596,776 & $1,369,607$ & $3,129,219$ & $13.90 \mathrm{HTU}$ \\
\hline Tuna Sirip Kuning & YFT & $1,195,266$ & $3,122,629$ & $1,578,751$ & 819,400 & $6,716,046$ & $29.83 \mathrm{HTU}$ \\
\hline Tuna Mata Besar & BET & $1,588,229$ & $2,683,529$ & $1,394,056$ & $1,926,392$ & $7,592,206$ & 33.72 HTU \\
\hline
\end{tabular}

Keterangan: HTS = Hasil Tangkapan Sampingan,

HTU = Hasil Tangkapan Utama 


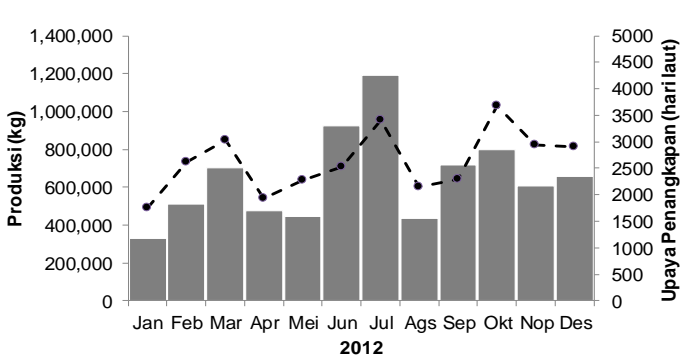

_ Produksi (kg) -๑- Jumlah Upaya Penangkapan (hari laut)

(a)

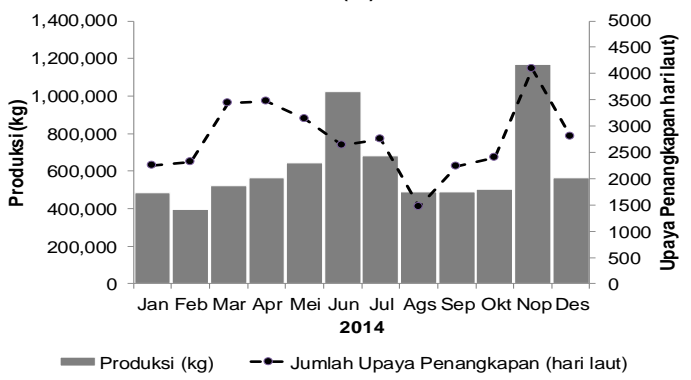

(c)

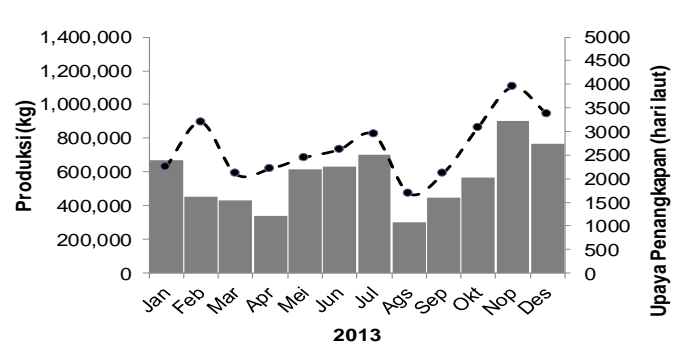

__ "Produksi (kg)" -๑- Jumlah Upaya Penangkapan (hari laut)

(b)

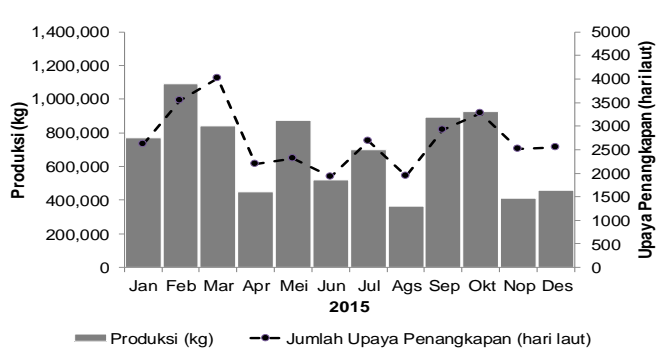

(d)

Gambar 5 Produksi dan upaya penangkapan rawai tuna di Pelabuhan Benoa tahun 2012 - 2015

Tabel 2 Hasil tangkapan per satuan upaya (CPUE) rawai tuna yang didaratkan di Pelabuhan Benoa tahun (2012-2015)

\begin{tabular}{|c|c|c|c|c|c|c|c|c|c|c|c|c|}
\hline \multirow[b]{2}{*}{ Bulan } & \multicolumn{3}{|c|}{2012} & \multicolumn{3}{|c|}{2013} & \multicolumn{3}{|c|}{2014} & \multicolumn{3}{|c|}{2015} \\
\hline & $\begin{array}{l}\text { Produksi } \\
\qquad(\mathrm{kg})\end{array}$ & $\begin{array}{l}\text { Upaya } \\
\text { (hr. laut) }\end{array}$ & $\begin{array}{l}\text { CPUE } \\
\text { (kg/hr. laut) }\end{array}$ & $\begin{array}{l}\text { Produksi } \\
\qquad(\mathrm{kg})\end{array}$ & $\begin{array}{l}\text { Upaya } \\
\text { (hr. laut) }\end{array}$ & $\begin{array}{l}\text { CPUE } \\
\text { (kg/hr. laut) }\end{array}$ & $\begin{array}{l}\text { Produksi } \\
\qquad(\mathrm{kg})\end{array}$ & $\begin{array}{l}\text { Upaya } \\
\text { (hr. laut) }\end{array}$ & $\begin{array}{l}\text { CPUE } \\
\text { (kg/hr. laut) }\end{array}$ & $\begin{array}{c}\text { Produksi } \\
(\mathrm{kg})\end{array}$ & $\begin{array}{l}\text { Upaya } \\
\text { (hr. laut) }\end{array}$ & $\begin{array}{l}\text { CPUE } \\
\text { (kg/hr. laut) }\end{array}$ \\
\hline Jan & 331,051 & 1,750 & 189 & 668,615 & 2,247 & 298 & 482,776 & 2,244 & 215 & 768,969 & 2,624 & 293 \\
\hline $\mathrm{Feb}$ & 512,552 & 2,625 & 195 & 450,583 & 3,195 & 141 & 394,706 & 2,319 & 170 & $1,089,941$ & 3,544 & 308 \\
\hline Mar & 700,786 & 3,039 & 231 & 429,726 & 2,102 & 204 & 523,635 & 3,437 & 152 & 839,293 & 4,017 & 209 \\
\hline Apr & 474,312 & 1,927 & 246 & 337,593 & 2,205 & 153 & 564,836 & 3,478 & 162 & 447,201 & 2,201 & 203 \\
\hline Mei & 444,558 & 2,271 & 196 & 613,055 & 2,447 & 251 & 644,249 & 3,142 & 205 & 872,761 & 2,309 & 378 \\
\hline Jun & 923,257 & 2,521 & 366 & 629,116 & 2,616 & 241 & $1,021,506$ & 2,639 & 387 & 520,078 & 1,921 & 271 \\
\hline Jul & $1,188,903$ & 3,413 & 348 & 701,130 & 2,933 & 239 & 681,841 & 2,746 & 248 & 699,818 & 2,692 & 260 \\
\hline Ags & 437,737 & 2,157 & 203 & 300,385 & 1,689 & 178 & 487,455 & 1,462 & 333 & 365,353 & 1,942 & 188 \\
\hline Sep & 716,550 & 2,285 & 314 & 449,931 & 2,113 & 213 & 491,357 & 2,233 & 220 & 892,109 & 2,922 & 305 \\
\hline Okt & 798,614 & 3,681 & 217 & 564,843 & 3,082 & 183 & 502,934 & 2,408 & 209 & 926,319 & 3,277 & 283 \\
\hline Nop & 605,785 & 2,945 & 206 & 903,475 & 3,939 & 229 & $1,167,701$ & 4,086 & 286 & 412,929 & 2,506 & 165 \\
\hline Des & 657,098 & 2,908 & 226 & 767,500 & 3,365 & 228 & 562,105 & 2,799 & 201 & 456,454 & 2,546 & 179 \\
\hline Total & $7,791,205$ & 31,521 & 2,937 & $6,815,951$ & 31,932 & 2,558 & $7,525,103$ & 32,992 & 2,789 & $8,291,226$ & 32,501 & 3,042 \\
\hline Rata-rata & 649,267 & 2,627 & 245 & 567,996 & 2,661 & 213 & 627,092 & 2,749 & 232 & 690,935 & 2,708 & 253 \\
\hline
\end{tabular}

Pada periode 2012-2014 fluktuasi produksi sebanding dengan besarnya upaya penangkapan dan jumlah kapal yang beroperasi. Namun, pada tahun 2015 terjadi kenaikan hasil produksi dengan kenaikan upaya penangkapan yang tinggi pula meskipun dengan jumlah armada yang menurun akibat pelaksanaan moratorium perikanan tangkap KKP. Penurunan jumlah armada di tahun 2015 adalah sebesar 159 unit dibandingkan dengan tahun sebelumnya (Gambar 1). Rata-rata peningkatan produksi di tahun 2015 adalah sebesar 10\% dibandingkan tahun sebelumnya. Hal ini terjadi pula dengan nilai CPUE (Tabel 2).

Rata-rata produksi, upaya penangkapan dan CPUE rawai tuna sebelum moratorium (2012-2014) dibandingkan nilai rata-rata produksi, upaya penangkapan dan CPUE tahun 2015 (setelah moratorium) menunjukkan hasil yang tidak signifikan (berbeda) dengan nilai $\mathrm{F}$ hitung $(0,621)<\mathrm{F}$ tabel (2.82), dan Sig $(0,605)>\alpha(0,05)$; F hitung $(0,083)<\mathrm{F}$ tabel $(2,82)$ dan Sig $(0,969)>\alpha$ $(0,05)$ dan $F$ hitung $(0,973)<F$ tabel $(2,82)$ dan Sig $(0,414)>a(0,05)$. 


\section{PEMBAHASAN}

\section{Armada Rawai Tuna dan Cakupan Data Enumerasi}

Pada tahun 2006 sampai dengan 2010 terdapat penurunan jumlah armada rawai tuna yang mendaratkan hasil tangkapan di Pelabuhan Benoa-Bali. Pada tahun-tahun tersebut perikanan rawai tuna industri dihadapkan pada berbagai macam kendala sebagai dampak dari kenaikan harga minyak. Kenaikan harga minyak sangat berpengaruh terhadap biaya operasional dan total produksi hasil tangkapan (Nugraha \& Hufiadi 2012). Menurut (Barata et al. 2011; Rochman \& Nugraha. 2014), perikanan rawai tuna di Pelabuhan Benoa adalah merupakan perikanan rawai tuna segar dimana aktivitas penangkapan dilakukan di laut lepas (high seas) dan sangat jauh dari tepi pantai. Daerah penangkapan umumnya dilakukan di luar Zona Ekonomi Ekslusif (ZEE) dengan area diatas $15^{\circ}$ LS di laut Samudera Hindia. Sehingga kebutuhan bahan bakar minyak sangat tinggi. Biaya pemakaian bahan bakar minyak mencapai $28-60 \%$ dari total keseluruhan biaya produksi (Sumaila et al. 2008; Schau et al. 2009; Rochman \& Nugraha 2014). Pada tahun 2006 sampai dengan 2010 terdapat kenaikan berjenjang harga minyak hingga mencapai $114,28 \%$ (Rp 2.100 to $\operatorname{Rp~} 4.500$ ) dari harga awal. Hal itu menyebabkan kenaikan biaya operasional perikanan rawai tuna yang ditandai dengan ditemukannya beberapa perusahaan yang mengurangi jumlah armada dan hari operasinya (Nugraha \& Hufiadi 2012). Pengurangan itu menyebabkan penurunan total produksi tuna yang didaratkan di Pelabuhan Benoa. Produksi perikanan tuna tertinggi diperoleh pada tahun 2009 sebesar 17.421 ton dan selanjutnya terdapat penurunan produksi di tahun 2010 sebesar 10.075 ton (ATLI 2010). ATLI (2010), menyatakan bahwa terdapat fluktuasi produksi di tahun 2009-2010 akibat pengurangan jumlah armada dan hari operasi di tahun 2010 (Gambar 6). Salah satu contoh dikemukakan oleh Hapsari (2006), yang menyatakan bahwa total produksi perikanan rawai tuna yang dimiliki oleh PT Perikanan Samudra Besar (sekarang PT Perikanan Nusantara), sebelum dan setelah kenaikan harga minyak menurun sebesar $14,37 \%$ dari tahun sebelumnya.

Pada tahun 2010 sampai dengan 2014, jumlah armada rawai tuna di Pelabuhan Benoa stabil pada kisaran 753 hingga 1.099 unit. Hal itu disebabkan karena nelayan rawai tuna telah mampu beradaptasi dengan naik turunnya harga minyak melalui penerapan manajemen penangkapan yang baik, menekan biaya pengeluaran dan penentuan area penangkapan yang tepat sesuai dengan kondisi lingkungan yang ada (Rochman et al. 2016a).

Memasuki akhir tahun 2014 dan pertengahan tahun 2015, pemerintah Indonesia melalui Kementerian Kelautan dan Perikanan (KKP) mengeluarkan peraturan yang menghentikan kegiatan operasional kapalkapal rawai tuna yang pembangunannya dilakukan di luar negeri. Peraturan ini menyebabkan penurunan jumlah armada rawai tuna di Pelabuhan Benoa sebesar 150 unit. Menurut (Davies et al. 2014), kapasitas berlebih pada industri rawai tuna baik dalam jumlah kapal yang beroperasi dan kemampuan dalam menangkap dan menyimpan ikan adalah merupakan hal yang serius dalam manajemen perikanan dan konservasi stok tuna yang mengakibatkan tangkapan berlebih dan pemborosan ekonomi. Sejalan dengan pernyataan diatas, tujuan dikeluarkannya peraturan tersebut adalah untuk mengaktualisasikan pengelolaan perikanan yang bertanggung jawab dan penanggulangan penangkapan ikan ilegal, tidak dilaporkan, tidak diatur (ilegal, unreported and unregulated, IUU) di Wilayah Pengelolaan Perikanan Indonesia (FMA).

Pada periode Januari 2012 sampai dengan Desember 2015 terdapat 3.085 unit kapal yang mendaratkan hasil tangkapan di Pelabuhan Benoa dan 1.851 unit diantaranya telah dapat dienumerasi dengan cakupan data sebesar $60 \%$. Cakupan data ini adalah lebih besar dari persyaratan minimum yang dikeluarkan oleh IOTC sebesar minimum $30 \%$ (IOTC 2002). Menurut (Jatmiko et al. 2017), persentase cakupan data meningkat setengahnya dari $40 \%$ di tahun 2010 menjadi $60 \%$ di tahun 2015 . Umumnya, persentase kapal yang terobservasi meningkat sekitar $7 \%$ sampai $12 \%$ dari tahun 2012 hingga 2015.

\section{Produksi, CPUE dan Komposisi Hasil Tangkapan}

Pada umumnya, rawai tuna di Pelabuhan Benoa didominasi oleh tipe rawai laut dalam dan pertengahan dengan jumlah pancing berkisar antara 12-18 pancing diantara pelampung hook between float 


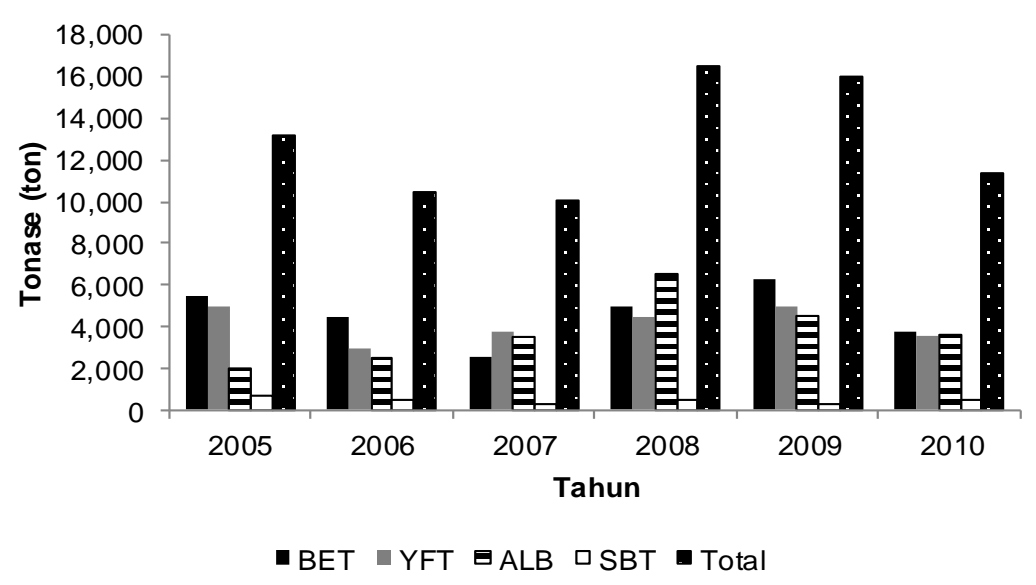

Gambar 6 Estimasi hasil tangkapan tuna yang didaratkan di Pelabuhan Benoa tahun 2005- 2010 (ATLI 2010)

(HBF), dengan kedalaman pancing antara 117- 450 meter (Barata et al. 2011; Novianto \& Nugraha 2014). Jenis rawai ini beroperasi di dalam dan dibawah lapisan thermoklin dengan kedalaman antara 118 sampai dengan 291 meter (Chen et al. 2005; Domokos et al. 2007; Latumeten et al. 2013; Williams et al. 2014; Rochman et al. 2016b). Jenis rawai tuna ini difokuskan pada tuna laut dalam dan ikan berparuh seperti tuna sirip kuning, tuna mata besar, albakora, tuna sirip biru selatan, ikan pedang, marlin, layaran dan todak (Nugraha \& Triharyuni 2009; Rochman et al. 2016b). Hal ini menghasilkan komposisi hasil tangkapan yang didominasi oleh empat jenis tuna dan enam jenis ikan berparuh dengan komposisi sebesar 93,77\% (Gambar 5). Selain itu terdapat beberapa spesies yang merupakan hasil tangkapan sampingan diantaranya jenis hiu, gindara, bawal laut, lamadang, cakalang, layur dan tengiri dalam porsi yang tidak terlalu besar, yaitu berkisar $6,23 \%$ dari total hasil tangkapan. Sebagai hasil tangka-pan sampingan, spesies hiu ditangkap menggunakan rawai permukaan yang dikaitkan pelampung dengan kedalaman pancing tidak lebih dari 10 meter dan biasanya menggunakan daging ikan gindara sebagai umpan. Suhu air pada kedalaman kurang dari 10 meter berada pada kisaran $22^{\circ} \mathrm{C}$ (Rochman et al. 2016b) yang mana dilapisan air tersebut kaya akan produktivitas primer terutama diatom yang berasosiasi dengan kelimpahan dan keanekaragaman ikan jenis teleostei dan Chondrichthyans (Lamberth et al. 1995; Clark et al. 1996). Jenis teleosts ada Chondrichthyans adalah merupakan mangsa dari spesies hiu (Kock et al. 2013; Weltz et al. 2013). Kepadatan mangsa merupakan faktor eksternal yang berpengaruh terhadap penyebaran dan laju tangkap hiu (Sims et al. 2003; Brown et al. 2010; Hammerschlag et al. 2012; Tickler et al. 2017).

Pada tahun 2012-2014, upaya penangkapan berkorelasi positif dengan jumlah kapal yang beroperasi, tetapi pada tahun 2015 upaya penangkapan menunjukkan angka peningkatan meskipun terdapat penurunan jumlah armada tangkap. Hal itu disebabkan kenaikan hasil tangkapan diikuti dengan kenaikan frekuensi penitipan hasil tangkapan menggunakan kapal angkut. Satu kali penitipan hasil tangkapan di kapal pengangkut dihitung sebagai satu kali upaya penangkapan armada rawai tuna. Pada umumnya, armada rawai tuna menitipkan hasil tangkapan satu kali selama dua minggu namun memasuki tahun 2015 menjadi dua kali selama dua minggu. Sehingga hal ini menyebabkan kenaikan jumlah upaya penangkapan.

\section{KESIMPULAN}

Perkembangan rawai tuna skala industri di Pelabuhan Benoa-Bali dari tahun ke tahun sangat dinamis baik dari segi perubahan jumlah armada, produksi hasil tangkapan dan upaya penangkapan. Jumlah armada rawai tuna pada periode 2012 sampai dengan 2015 terjadi penurunan yang signifikan dikarenakan oleh kebijakan pemerintah pada akhir tahun 2014 dan awal 2015 yang melarang penggunaan dan aktivitas kapal yang pembangunannya di luar negeri (eks asing). Penurunan jumlah ar- 
mada tangkap mestinya diikuti oleh penurunan produksi dan upaya penangkapan seperti yang dapat dilihat pada periode 2012 sampai dengan 2014. Namun pada periode tahun 2015, penurunan jumlah armada tangkap tidak diikuti dengan penurunan produksi dan upaya penangkapan. Namun sebaliknya, dimana rata-rata produksi dan upaya penangkapan mengalami kenaikan meskipun secara statistik tidak signifikan.

Program monitoring dan pencatatan hasil tangkapan (enumerasi) mengalami perbaikan dari waktu ke waktu dengan cakupan data sampling meningkat sebesar $10,3 \%$ dari $58 \%$ di tahun 2012 menjadi $64 \%$ di tahun 2015. Cakupan data sampling ini telah melebihi persyaratan utama IOTC dimana disyaratkan minimum cakupan data sebesar $30 \%$.

\section{SARAN}

Perikanan rawai tuna skala industri di Pelabuhan Benoa merupakan perikanan laut lepas dengan mayoritas daerah penangkapan diluar Zona Ekonomi Ekslusif atau laut internasional. Tipe perikanan rawai tuna ini membutuhkan energi dan biaya yang sangat besar dalam pengoperasiannya. Setelah penerapan moratorium perikanan tangkap tahun 2014 dan 2015, oleh pemerintah melalui KKP diharapkan penataan ulang armada rawai tuna di Indonesia telah selesai. Selanjutnya diharapkan adanya subsidi dan kemudahan bagi nelayan rawai tuna skala industri karena daerah penangkapannya diluar ZEE dan berada di zona laut Internasional. Kemudahan tersebut berupa kemudahan perijinan, penggunaan bahan bakar bersubsidi dan pindah muat transhipment terbatas dan terkontrol. Kemudahan tersebut harus juga diikuti dengan kepatuhan pelaku industri rawai akan ketentuan yang telah digariskan oleh pemerintah melalui KKP. Diantaranya adalah kepatuhan dalam penggunaan VMS (vessel monitoring system), penempatan observer, dan kepatuhan untuk mengirimkan hasil tangkapan di pelabuhan-pelabuhan perikanan di Indonesia.

\section{UCAPAN TERIMA KASIH}

Tulisan ini merupakan kontribusi dari kegiatan enumerasi yang dilakukan di pelabuhan Benoa dari tahun 2012 sampai dengan 2015. Peneliti mengucapkan terima kasih kepada para enumerator di Loka Riset Perikanan Tuna (LRPT) Benoa yang telah membantu dalam proses pengumpulan data penelitian ini.

\section{DAFTAR PUSTAKA}

ATLI (Asosiasi Tuna Longline Indonesia). 2010. Nominal Catch by Species. Indonesian Tuna Longline Association. Benoa. 2 pp.

Barata, A, Novianto D, Bahtiar A. 2011. Sebaran Ikan Tuna Berdasarkan Suhu dan Kedalaman di Samudera Hindia. Jurnal IImu Kelautan Indonesia. 16(3): 165-170.

Brown AC, Lee DE, Bradley RW, Anderson S. 2010. Dynamic of White Shark Predation on Pinnipeds in California: Effect of Prey Abundance. Copeia; May 20, 2010; Biological Science Database. $232 \mathrm{p}$.

Chen IC, Lee PF, Tzeng NW. 2005. Distribution of Albacore (Thunnus alalunga) in the Indian Ocean and its Relation to Environmental Factor. Fish Oceanography. 14(1): 71-80.

Clark BM, Bennett BA, Lambert SJ. 1996. Temporal Variationin Surf Zone Fish Assemblages from False Bay, South Africa. Mar Ecol Prog Ser. 131: 35-47.

Davies TK, Chris C, Milner-Gulland EJ. 2014. Modelling the Spatial Behaviour of a Tropical Tuna Purse Seine Fleet. PLOS ONE. 9(12): e114037. doi:10. 137/jounal.pone.-0114037.

DGCF (Directorate General of Capture Fisheries). 2014. Statistics of Marine Capture Fisheries 2014. Directorate General of Capture Fisheries, MMAF. Jakarta.

Domokos R, Seki MP, Polovina, Hawn JJDR. 2007. Oceanographic Investigation of the American Samoa Albacore (Thunnus alalunga) Habitat and Longline Fishing Grounds. Fish. Oceanography. 16: 555-572.

Furchan A. 2004. Pengantar Penelitian dalam Pendidikan. Yogyakarta: Andi Offset. 
Gunarso W, Wiyono ES. 1994. The Study on Influence of Season and Catch Technology to the Catch of Mackerel ( $D e$ capterus sp.) in Java Sea. Bulletin of ITK Marite. 4(1): 55-58.

Hammerschlag N, Luo J, Irschick DJ, Ault JS. 2012. A Comparison of Spatial and Movement Patterns Between Sympatric Predators: Bull Sharks (Carcharhinus leucas) and Atlantic Tarpon (Megalops atlanticus). PLOS ONE. 7(9): e45958. doi:10.1371/journal. pone.0045958.

Hapsari AT. 2006. Optimalisasi Produksi Usaha Penangkapan Tuna Pasca Kenaikan Harga BBM pada PT Perikanan Samodra Besar Cabang Benoa Bali. [Skripsi]. Bogor: Manajemen Bisnis dan Ekonomi Perikanan dan Kelautan. Fakultas Perikanan dan IImu Kelautan. Institut Pertanian Bogor. 82 pp.

Hutapea RYF, Solihin I, Nurani TW. 2017. Peran Pelabuhan Perikanan Samudera Nizam Zachman dalam Mendukung Industri Tuna. Marine Fisheries. 8(2): 187-198.

IOTC (Indian Ocean Tuna Commission). 2002. Field Manual for Data Collection on Tuna Landing from Longliners. IOTC Secretariat. Seychelles. 21 pp.

IOTC (Indian Ocean Tuna Commission). 2012. Indonesian National Report to the Scientific Committee of the Indian Ocean Tuna Commission 2012. IOTC2012-NR 10 Rev_1. 18.

Jatmiko I, Rochman F, Fahmi Z. 2017. Enumeration Methods Used to Investigated the Production of Yellowfin Tuna (Thunnus albacares) in Indian Ocean; Case Study of Tuna Monitoring in Benoa Port, Bali, Indonesia. 2nd International Forum on Sustainable Future in Asia, 2nd NIES International Forum January 26-28, 2017 Bali, Indonesia. 20-25 pp.

Kock A, O'Riain MJ, Mauf K, Meyer MA, Kotze D. 2013. Residency Habitat Use and Sexual Segregation of White Shark, Carcharodon carcharias in False Bay, South Africa. PLoS ONE. 8(1): e55048.https://doi.org/10.1371/journal. pone.00 55048
Lamberth SJ, Clark BM, Bennett BA.1995. Seasonal of Beach Seine Catches in False Bay, South Africa and Implication for Management. S. Afr. J. Mar. Sci. 15: 157-167.

Latumeten AL, Purwanti F, Hartoko A. 2013. The Analysis of Relationship Between Sea Surface Temperature, Chlorophyll-a of Modis Satelite Data and Subsurface Temperature of Argo Float Data to the Number of Tuna Catches in Indian Ocean. Management of Aquatic Resource Journal. Diponegoro University. 2(2): 1-8.

Moreno G, Herrera M. 2013. Estimation of Fishing Capacity by Tuna Fishing Fleets in Indian Ocean. IOTC-2013SC16-INF 04.p.76.

Novianto D, Nugraha B. 2014. Komposisi Hasil Tangkapan Sampingan dan Ikan Target Perikanan Rawai Tuna Bagian Timur Samudera Hindia. Marine Fisheries. 5(2): 119-127.

Nugraha B, Triharyuni S. 2009. The Effect of Temperature and Hook Depth of Tuna Longline to Catch of Tuna in Indian Ocean. Indonesian Fisheries Research Journal. Research Centre for Fisheries Management and Conservation. Indonesian Fisheries and Marine Affairs. 15(3): 239-247.

Nugraha B, Hufiadi. 2012. Produktivitas Perikanan Tuna Longline di Benoa (Studi Kasus: PT. Perikanan Nusantara. Mari-ne Fisheries. 3(2): 135-140.

Pillai NGK, Satheskhumar. 2013. Conservation and Management of Tuna Fisheries in Indian Ocean and Indian EEZ. International Journal of Marine Science. 3(24): 187-192.

Proctor $\mathrm{CH}$, Mertal GS, Sondita MFA, Wahju RI, Davis TLO, Gunn JS, Andamari R. 2003. A Review of Indonesian Ocean Tuna Fisheries. ACIAR Country Status Report. p. 106.

Rochman F, Nugraha B. 2014. Productivity and Economic Analysis of the Indian Ocean Longline Fishery Landed at Benoa Port Bali Indonesia. Indonesian Fisheries Research Journal. 20(2): 7686. 
Rochman F, Setyadji B, Jatmiko I. 2016a. Impact of Moratorium Enforcement on The Fishing Effort and Production of Industrial Scale Longline Tuna Fisheries Based in Benoa Port, Bali. Jurnal Penelitian Perikanan Indonesia. 22(3): 181-188.

Rochman F, Pranowo W, Jatmiko I. 2016b. The Influence of Swimming Layer and Sub-surface Oceanographic Variables on Catch of Albacore (Thunnus alalunga) in Eastern Indian Ocean. Indonesian Fisheries Research Journal. 22(2): 69-76.

Schau EM, Ellingsen H, Endal A, Aanonsend SA. 2009. Energy Consumption in Norwegian Fisheries. Journal of Cleaner Production. 17: 325- 334.

Sims DW, Southall EJ, Merrett DA, Sanders J. 2003. Effect of Zooplankton Density and Diel Period on Surface Swimming Duration of Basking Sharks. J. Mar. Biol. Ass. U.K. 83: 643-646.

Sugiyono. 2008. Metode Penelitian Kuantitatif Kualitatif dan $R$ \& $D$. Bandung: ALFABETA.
Sumaila UR, The L, Watson R., Tyedmers $P$, Pauly D. 2008. Fuel Price Increase, Subsidies, Overcapacity, and Resource Sustainability. ICES Journal of Marine Science. 65: 832-840.

Tickler DM, Letessier TB, Koldewey HJ, Meeuwig JJ. 2017. Drivers of Abundance and Spatial Distribution of Reef-associated Sharks in an Isolated Atoll Reef System. PLOS ONE 12(5): e0177374. https://doi.-org/10.1371/ journal.pone.0177374.

Weltz K, Kock AA, Winker H, Attwood C, Sikweyiya M. 2013. The Influence of Environmental Variables on the Presence of White Sharks, Carcharodon carcharias at Two Popular Cape Town Bathing Beaches: A Generalized Additive Mixed Model. PLOS ONE 8(7): e68554. doi:10.1371/journal.pone.00.

Williams AJ, Allain V, Nicol JJ, Evans KJ, Hoyle SD, Dupoux C, Vaorey E, Dubosc J. 2014. Vertical Behavior and Diet of Albacore Tuna (Thunnus alalunga) Vary with Latitude in the South Pacific Ocean. Deep-Sea Res. II http://dx.doi.org/10.1016/j.dsr2.2014.0 3.010 